\title{
Performance of Wheat Varieties (Triticum aestivum L.) under Conservation Tillage Practices in Organic Agriculture
}

\author{
Dimitrios BILALIS ${ }^{1 *}$, Anestis KARKANIS², Sotiria PATSIALI ${ }^{1}$, Maria AGRIOGIANNI ${ }^{1}$ \\ Aristeidis KONSTANTAS ${ }^{1}$, Vassilios TRIANTAFYLLIDIS ${ }^{3}$ \\ ${ }^{1}$ Agricultural University of Athens, Department of Crop Science, Iera Odos 75, 11855 \\ Athens, Greece; bilalisdimitrios@yahoo.gr (*corresponding author) \\ ${ }^{2}$ University of Thessaly, Department of Agriculture Crop Production and Rural Environment, Fytokou Street, 38466, N. Ionia, Volos, Greece \\ ${ }^{3}$ University of Ioannina, Department of Business Administration of Food and Agricultural Products, 20 G. Seferi Str, 30100 Agrinio, Greece
}

\begin{abstract}
Field experiments were conducted to determine the effects of tillage systems and varieties on growth, yield and quality of wheat crop (Triticum aestivum L.). The experiments conducted at two sites were laid out in a split-plot design with four replicates, three main plots [conventional tillage (CT), no-tillage (NT) and minimum tillage (MT)] and four sub-plots ('Siette,' 'Panifor,' 'Myrto', 'Estero'). The soil porosity and total nitrogen were higher in soils subjected to conservation tillage systems (NT and MT) than under conventional tillage. There were no differences in root growth neither between the tillage systems nor among the varieties. Yield was influenced by the tillage system and variety. The highest grain yield ( $\left.421-459 \mathrm{~kg} \mathrm{ha}^{-1}\right)$ was found under the CT system with 'Siette,' 'Myrto' and 'Estero' varieties. In contrast, the highest grain yield was observed under conservation tillage (NT and MT) with 'Panifor' variety. There were no significant differences between the tillage systems concerning the protein content and Zeleny value. In contrast, the highest Hagberg falling number was found with MT. Zeleny value was positively and significantly correlated with protein content. High flour quality, as demonstrated by high protein content and Zeleny value, and low Hagberg falling number, was produced in the 'Estero' variety.
\end{abstract}

Keywords: conventional tillage, Hagberg falling number, minimum tillage, no-tillage, quality, Zeleny value

\section{Introduction}

Conservation tillage covers a range of tillage practices which aim to conserve soil moisture and reduce soil erosion by leaving more than one-third of the soil surface covered by crop residues. Conservation tillage includes a shallow working depth without soil inversion, i.e. no tillage, or reduced or shallow tillage with tines or discs (Peigne et al., 2007). Understanding the effects of conservation tillage practices on soil structure is critical for suitable soil management (Daraghmeh et al., 2009). Conservation tillage (no-tillage and minimum tillage) systems generally improve soil organic C, plant-available water capacity, aggregation and soil water transmission (Bhattacharyya et al., 2008). Alvarez (2005) reported that no differences in soil organic carbon (SOC) were found between reduced tillage (chisel, disc and sweep till) and no-tillage, whereas conventional tillage (mouldboard plough, disc plough) was associated with less SOC. Conservation tillage can be beneficial for soil, water and soil organic matter conservation in Mediterranean areas that are prone to soil erosion and where water availability for crops is the main factor for sustainability (Cantero-Martinez et al., 2007). Soil organic matter is crucial for maintaining soil quality. Carbon sequestration in agricultural soils can contribute to offset- ting anthropogenic $\mathrm{CO}_{2}$ emissions and also to enhancing soil fertility, soil water retention and crop production (Alvaro-Fuentes et al., 2009).

Moreover, no-tillage is becoming increasingly attractive to farmers because it clearly reduces production costs relative to conventional tillage (DeVita et al., 2007). Notillage has been adopted worldwide as a strategy to reduce the negative effects of soil erosion brought about by conventional tillage (Cavalieri et al., 2009). Adoption and successful implementation of no-tillage is strongly dependent on the farmer's knowledge of the technology involved in such a system.

Data obtained by other researchers (Bhattacharyya et al., 2008; Mrabet, 2000; Sidiras et al., 2001; Sip et al., 2009) demonstrate the beneficial effects of conservation tillage on the yields of cereal crops in conventional farming. The success of conservation tillage in organic farming hinges on the choice of crop rotation to ensure weed and disease control and nitrogen availability (Bilalis et al., 2001; Peigne et al., 2007). Organic farmers are encouraged to adopt conservation tillage to preserve soil quality and fertility and to prevent soil degradation and compaction.

It is estimated that more than $95 \%$ of organic production is based on crop varieties that were bred for the conventional high-input sector. Recent studies have shown 
that such varieties lack important traits required under organic and low-input production conditions. Some of the traits (e.g. semi-dwarf genes) that were introduced to address problems such as lodging in cereals in high-input systems were shown to have negative side-effects (lower protein content and poorer nutrient-use efficiency) on the performance of varieties under organic and low-input agronomic conditions (Lammerts van Bueren et al., 2010; Li et al., 2010). Specific breeding for organic systems may help reduce their yield gap relative to conventional systems by exploiting genotype $\times$ system interaction (Annicchiarico et al., 2010). The main objective of this study was to evaluate the effect of tillage system on soil properties, growth, grain yield and quality of wheat crop. It has been intended to evaluate the performance of four wheat varieties under organic conditions.

\section{Material and methods}

\section{Field trials}

The experiment was repeated twice. A winter wheat crop (Triticum aestivum L.) was established in the experimental field of the Agricultural University of Athens $\left(23^{\circ} 43^{\prime} \mathrm{E}\right.$, $\left.34^{\circ} 58^{\prime} \mathrm{N}\right)$ in 2007 . The soil was clay loam $(29.8 \%$ clay, $34.3 \%$ silt and $35.9 \%$ sand) with $\mathrm{pH} 7.24, \mathrm{NO}_{3}-\mathrm{N} 12.4$ $\mathrm{mg} \mathrm{kg}^{-1}$ soil, P $13.2 \mathrm{mg} \mathrm{kg}^{-1}$ soil, $\mathrm{K} 201 \mathrm{mg} \mathrm{kg}^{-1}$ soil. Annual temperature and precipitation were $18.11^{\circ} \mathrm{C}$ and $420 \mathrm{~mm}$, respectively. In parallel, a wheat crop was established in the Agrinio area (western Greece, Lat: $38^{\circ} 35^{\prime}$, Long: $21^{\circ} 25^{\prime}$ ) in 2008 . The soil was a clay loam $(24.9 \%$ clay, $61.2 \%$ silt, and $13.9 \%$ sand) with $\mathrm{pH} 7.4$, organic matter $1.45 \%$, EC $0.63 \mathrm{mS} \mathrm{cm}^{-1}, 0.152 \%$ total nitrogen and a sufficient supply of phosphorus (P Olsen $175 \mathrm{ppm}$ ) and potassium (632 $\mathrm{ppm})$. Annual temperature and precipitation were $17.2^{\circ} \mathrm{C}$ and $955 \mathrm{~mm}$, respectively. Some meteorological data of the experimental sites are presented in Fig. 1. The sites were managed according to organic agriculture guidelines (EC 834/2007).

The experiments were set up on an area of $820 \mathrm{~m}^{2}(34$ $\mathrm{m} \times 24 \mathrm{~m}$ ) according to the split-plot design with four

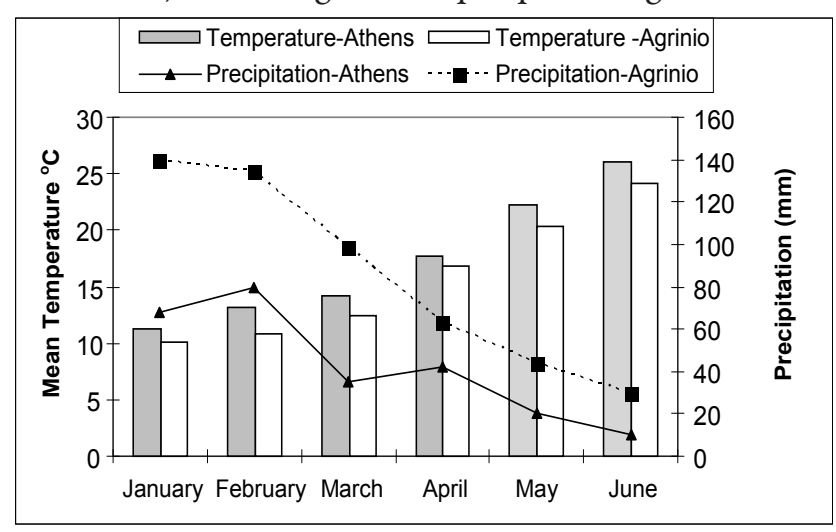

Fig. 1. Meteorological data (temperature: ${ }^{\circ} \mathrm{C}$ and precipitation: $\mathrm{mm}$ ) for the experimental sites during the experimental periods (January-June). replicates, three main plots (conventional tillage: CT, moldboard plowing at $20-25 \mathrm{~cm}$, followed by one rotary hoeing at $5-10 \mathrm{~cm}$; minimum tillage: MT, chiseling at 20 $\mathrm{cm}$ depth followed by one rotary hoeing at $5-10 \mathrm{~cm}$; notillage: NT: no tillage, direct sowing (in the row, hand tilling ( $5 \mathrm{~cm}$ deep) was performed before wheat sowing) and four sub-plots (wheat varieties: 'Panifor', Ester, 'Myrto,' 'Siete Serros'). The main-plot size was $250 \mathrm{~m}^{2}$. This study was part of a long-term experiment started in 2005 and 2006, in Athens and Agrinio, respectively. At each site, the tillage treatments were repeated every year on the same plots. The crop cultivated before the wheat was vetch (Vicia sativa L. cv. 'Alexander'). Wheat was sown by hand in rows $18 \mathrm{~cm}$ apart at a depth of $3 \mathrm{~cm}$. Wheat was sown on 21 November 2007 and 20 November 2008 at a rate of 220 $\mathrm{kg} \mathrm{ha}^{-1}$. Finally, weeds were controlled by hand at 60 and 120 days after sowing.

\section{Sampling, measurements and methods}

Total porosity of the soil was determined by 1-Db/ $\mathrm{Dp}$, where $\mathrm{Dp}$ is the particle density $\left(2.5 \mathrm{~g} \mathrm{~cm}^{-3}\right)$ and $\mathrm{Db}$ is the soil bulk density. Soil bulk density was determined for each plot by taking undisturbed soil cores with $100 \mathrm{~cm}^{3}$ cylinders from a depth of $0-10 \mathrm{~cm}$. Three samples of 100 $\mathrm{cm}^{3}$ per plot were taken [220 days after sowing (DAS)]. The undisturbed samples were finally oven dried at $100^{\circ} \mathrm{C}$ for $24 \mathrm{~h}$ to obtain soil dry mass and the soil bulk density was calculated as follow: $\mathrm{Db}=\operatorname{dry}$ mass $(\mathrm{g}) / 100 \mathrm{~cm}^{3}$. The total nitrogen was determined by the Kjeldahl method (Bremner, 1960) using a Buchi 316 device in order to combust and extract the soil samples.

For the computation of height and tillers, 10 plants were randomly selected in each plot. Root samples were collected 75 DAS and from the $0-25 \mathrm{~cm}$ layer by using a cylindrical auger $(25 \mathrm{~cm}$ length, $10 \mathrm{~cm}$ diameter) at the midpoint between successive plants within a row. For each sample, roots were separated from soil after standing for $24 \mathrm{~h}$ in water $+\left(\mathrm{NaPO}_{3}\right)_{6}+\mathrm{Na}_{2} \mathrm{CO}_{3}$. The root dry weight was then determined after drying one of the paired samples for $48 \mathrm{~h}$ at $70^{\circ} \mathrm{C}$. For the determination of the density and diameter of roots, the root samples were placed on a high-resolution scanner using DT software (Delta-T Scan version 2.04; Delta-T Devices Ltd, Burrwell, Cambridge, $\mathrm{UK})$.

The wheat seed yield also was determined by manually harvesting the plants in the two centre rows of each plot on $22^{\text {nd }}$ of June 2008 and $20^{\text {th }}$ of June 2009. 1000grain weight was estimated by randomly taking $4 \times 100$ grains from each plot. For the computation of ear length ten ears per plot were measured. Grain protein (\%) was calculated after multiplying Kjeldahl N by 5.7 (De Vita $e t$ al., 2007). The grain nitrogen content was determined by the Kjeldahl method. $\alpha$-Amylase activity (Hagberg falling number) was measured using the Hagberg recommended method (Hagberg, 1960; ISO-3093, 2004). Finally, the sedimentation test (Zeleny value) developed by ISO-5529 
30

was used for estimating the gluten strength of wheat grain (ISO-5529, 2007).

\section{Statistical analysis}

For calculating analysis of variance and comparisons of means, Statistica software (StatSoft 1996) was used. The LSD test was used to detect and separate the mean treatment differences. Correlation analyses were used to describe the relationships between growth parameters and yield components. All comparisons were made at the 5\% level of significance.

\section{Results and discussion}

\section{Soil properties}

The lowest porosity (35.5-37\%) and total N (0.121$0.133 \%$ ) were found under CT (Tab. 1). There were also statistically significant differences between MT and NT systems. The highest porosity was observed under NT. Networks of biopores created by plant and animal activity might accumulate in untilled cropping systems (Wuest, 2001). Bilalis et al. (2009) observed that no-till management considerably influenced the improvement of the physical and chemical soil properties and increased the earthworm abundance. Data obtained by other researchers (Alvaro-Fuentes et al., 2009; Bilalis et al., 2010; Cantero-Martinez et al., 2007; Cavalieri et al., 2009; László et al., 2007; Sidiras et al., 2001; Tangyuan et al. 2009) clearly demonstrated the beneficial effects of conservation tillage (NT and MT) on soil structure and fertility. Daraghmeh et al. (2009) found that compared to conventional tillage,

Tab. 1. Influence of tillage system (conventional tillage: CT, minimum tillage: $\mathrm{MT}$ and no-tillage: $\mathrm{NT}$ ) and wheat varieties ('Siette,' 'Panifor,' 'Myrto, 'Estero') on porosity (\%) and total nitrogen (\%) of soil, in Athens and in Agrinio

\begin{tabular}{|c|c|c|c|c|c|c|}
\hline Varieties & \multicolumn{6}{|c|}{ Tillage system } \\
\hline \multirow{2}{*}{ Porosity \% } & \multicolumn{3}{|c|}{ Athens } & \multicolumn{3}{|c|}{ Agrinio } \\
\hline & CT & NT & MT & $\mathrm{CT}$ & NT & MT \\
\hline 'Siette' & 37 & 43.75 & 41 & 36.5 & 41 & 39 \\
\hline 'Panifor' & 35.5 & 43.5 & 39.75 & 35 & 42.25 & 39.75 \\
\hline 'Myrto' & 36.25 & 44 & 41 & 34.5 & 42 & 40.25 \\
\hline 'Estero' & 37.5 & 43 & 39.75 & 36 & 40.75 & 40 \\
\hline $\mathrm{LSD}_{\text {tillage }}(\mathrm{P}=0.05)$ & \multicolumn{3}{|c|}{$2.02\left(\mathrm{~F}=8.04^{*}\right)$} & \multicolumn{3}{|c|}{$1.69\left(\mathrm{~F}=9.47^{*}\right)$} \\
\hline $\operatorname{LSD}_{\text {varicticis }}(\mathrm{P}=0.05)$ & \multicolumn{3}{|c|}{$2.45\left(\mathrm{~F}=1.28^{\mathrm{ns}}\right)$} & \multicolumn{3}{|c|}{$1.45\left(\mathrm{~F}=2.15^{\mathrm{ns}}\right)$} \\
\hline Total nitrogen $\%$ & $\mathrm{CT}$ & NT & MT & $\mathrm{CT}$ & NT & MT \\
\hline 'Siette' & 0.123 & 0.161 & 0.139 & 0.103 & 0.145 & 0.127 \\
\hline 'Panifor' & 0.122 & 0.169 & 0.151 & 0.114 & 0.151 & 0.123 \\
\hline 'Myrto' & 0.121 & 0.155 & 0.175 & 0.109 & 0.144 & 0.130 \\
\hline 'Estero' & 0.133 & 0.154 & 0.164 & 0.106 & 0.139 & 0.135 \\
\hline $\mathrm{LSD}_{\text {tillagc }}(\mathrm{P}=0.05)$ & \multicolumn{3}{|c|}{$0.02\left(\mathrm{~F}=8.12^{*}\right)$} & \multicolumn{3}{|c|}{$0.009\left(\mathrm{~F}=10.34^{* *}\right)$} \\
\hline $\operatorname{LSD}_{\text {varicticis }}(\mathrm{P}=0.05)$ & \multicolumn{3}{|c|}{$0.14\left(\mathrm{~F}=1.33^{\mathrm{ns}}\right)$} & \multicolumn{3}{|c|}{$0.12\left(\mathrm{~F}=1.78^{\mathrm{ns}}\right)$} \\
\hline
\end{tabular}

The $\mathrm{LSD}(\mathrm{P}=0.05)$ for tillage systems and wheat varieties are shown. F-test ratios are from ANOVA. ${ }^{* * *}$ Significant at $\mathrm{P}=0.05$ and $\mathrm{P}=0.01$, respectively, ns: not significant
Tab. 2. Influence of tillage system (conventional tillage: CT, minimum tillage: MT and no-tillage: NT) and wheat varieties ('Siette,' 'Panifor,' 'Myrto,' 'Estero') on diameter (mm) and density of wheat roots $\left(\mathrm{cm} \mathrm{cm}^{-3}\right)$, in Athens and in Agrinio

\begin{tabular}{|c|c|c|c|c|c|c|}
\hline Varieties & \multicolumn{6}{|c|}{ Tillage system } \\
\hline \multirow{2}{*}{ Root diameter $(\mathrm{mm})$} & \multicolumn{3}{|c|}{ Athens } & \multicolumn{3}{|c|}{ Agrinio } \\
\hline & $\mathrm{CT}$ & NT & MT & CT & NT & MT \\
\hline 'Siette' & 1.05 & 0.90 & 1.14 & 0.98 & 0.89 & 1.05 \\
\hline 'Panifor' & 1.08 & 1.19 & 1.02 & 1.01 & 0.93 & 1.03 \\
\hline 'Myrto' & 0.78 & 0.84 & 1.07 & 0.82 & 0.77 & 0.85 \\
\hline 'Estero' & 0.96 & 0.98 & 1.15 & 0.91 & 0.86 & 0.89 \\
\hline $\mathrm{LSD}_{\text {tillage }}(\mathrm{P}=0.05)$ & \multicolumn{3}{|c|}{$0.29\left(\mathrm{~F}=0.82^{\mathrm{ns}}\right)$} & \multicolumn{3}{|c|}{$0.16\left(\mathrm{~F}=1.45^{\mathrm{ns}}\right)$} \\
\hline $\mathrm{LSD}_{\text {varietice }}(\mathrm{P}=0.05)$ & \multicolumn{3}{|c|}{$0.21\left(\mathrm{~F}=0.74^{\mathrm{ns}}\right)$} & \multicolumn{3}{|c|}{$0.14\left(\mathrm{~F}=1.68^{\mathrm{ns}}\right)$} \\
\hline Root density $\left(\mathrm{cm} \mathrm{cm}^{-3}\right)$ & CT & NT & MT & CT & NT & MT \\
\hline 'Siette' & 3.68 & 3.32 & 3.71 & 3.73 & 3.67 & 3.81 \\
\hline 'Panifor' & 3.17 & 3.57 & 3.34 & 3.24 & 3.37 & 3.56 \\
\hline 'Myrto' & 2.48 & 3.62 & 3.00 & 2.67 & 2.78 & 3.08 \\
\hline 'Estero' & 2.56 & 2.98 & 2.86 & 2.78 & 3.12 & 2.98 \\
\hline $\mathrm{LSD}_{\text {tillage }}(\mathrm{P}=0.05)$ & \multicolumn{3}{|c|}{$0.63\left(\mathrm{~F}=0.24^{\mathrm{ns}}\right)$} & \multicolumn{3}{|c|}{$0.45\left(\mathrm{~F}=1.58^{\mathrm{ns}}\right)$} \\
\hline $\mathrm{LSD}_{\text {varictics }}(\mathrm{P}=0.05)$ & \multicolumn{3}{|c|}{$1.15\left(\mathrm{~F}=0.48^{\mathrm{ns}}\right)$} & \multicolumn{3}{|c|}{$0.50(\mathrm{~F}=6.56)$} \\
\hline
\end{tabular}

The LSD $(\mathrm{P}=0.05)$ for tillage systems and wheat varieties are shown. F-test ratios are from ANOVA. *Significant at $\mathrm{P}=0.05$, ns: not significant

reduced tillage improved soil structure through a combination of increased soil organic matter, reduced soil bulk density and increased proportion of larger aggregates. In addition, Sasal et al. (2006) found that total porosity under chisel plough was higher than under NT. Moreover, there were no significant differences between the wheat varieties concerning the soil properties. The maintenance of good soil physical conditions is extremely important to ensure satisfactory crop growth and high yields.

\section{Wheat growth and yield}

Concerning the emergence percentage, there were no significant differences between treatments. Moreover, there were no significant differences in root growth (root density and diameter) between CT, NT and MT systems (Tab. 2). In comparison, Munoz-Romero et al. (2010) found that the root length was greater under NT than under $\mathrm{CT}$ for most growth stages and depths. In contrast, the root diameter was not significantly affected by tillage treatments. Moreover, there were no significant differences in root growth between wheat varieties at the Athens site (Tab. 2).

The lowest height (Tab. 3) was found under NT. 'Estero' variety had lower height in comparison to the other varieties ('Siette', 'Panifor,' 'Myrto'). The highest number of tillers was found under conservation tillage systems (NT and MT). There were no significant differences in tillering and ear length between wheat varieties (Tab. 3 and 4). In contrast, 'Estero' and 'Myrto' gave higher 1000-grain weights in comparison to the other varieties. The highest 1000 -grain weight was found under CT. In comparison, De Vita et al. (2007) found that the highest 1000-grain weight was obtained under NT. 
Tab. 3. Influence of tillage system (conventional tillage: CT, minimum tillage: MT and no-tillage: NT) and wheat varieties ('Siette,' 'Panifor,' 'Myrto', 'Estero') on height (cm) and tillers per plant of wheat, in Athens and in Agrinio

\begin{tabular}{|c|c|c|c|c|c|c|}
\hline \multirow{3}{*}{$\begin{array}{c}\text { Varieties } \\
\text { Height }(\mathrm{cm})\end{array}$} & \multicolumn{6}{|c|}{ Tillage system } \\
\hline & \multicolumn{3}{|c|}{ Athens } & \multicolumn{3}{|c|}{ Agrinio } \\
\hline & $\mathrm{CT}$ & NT & MT & $\mathrm{CT}$ & NT & MT \\
\hline 'Siette' & 85.52 & 73.3 & 79.97 & 86.45 & 76.34 & 82.31 \\
\hline 'Panifor' & 80.47 & 72.8 & 80.8 & 81.03 & 74.23 & 81.34 \\
\hline 'Myrto' & 79.62 & 75.1 & 78.8 & 79.34 & 76.02 & 76.23 \\
\hline 'Estero' & 71.17 & 69.82 & 62.40 & 72.56 & 71.09 & 73.45 \\
\hline $\mathrm{LSD}_{\text {tillage }}(\mathrm{P}=0.05)$ & \multicolumn{3}{|c|}{$3.45\left(\mathrm{~F}=6.67^{*}\right)$} & \multicolumn{3}{|c|}{$2.13\left(\mathrm{~F}=10.56^{* *}\right)$} \\
\hline $\operatorname{LSD}_{\text {varictice }}(\mathrm{P}=0.05)$ & \multicolumn{3}{|c|}{$2.13\left(\mathrm{~F}=21.25^{* * *}\right)$} & \multicolumn{3}{|c|}{$1.47\left(\mathrm{~F}=33.49^{* * *}\right)$} \\
\hline Tillers per plant & CT & NT & MT & $\mathrm{CT}$ & NT & MT \\
\hline 'Siette' & 5.37 & 14.12 & 13 & 9.56 & 11.23 & 10.97 \\
\hline 'Panifor' & 7.25 & 13.37 & 13.62 & 8.89 & 12.01 & 11.45 \\
\hline 'Myrto' & 4.12 & 13.15 & 12.87 & 9.23 & 10.95 & 11.23 \\
\hline 'Estero' & 8.87 & 13.12 & 13.37 & 9.52 & 11.05 & 10.78 \\
\hline $\mathrm{LSD}_{\text {tillage }}(\mathrm{P}=0.05)$ & \multicolumn{3}{|c|}{$0.23\left(\mathrm{~F}=77.73^{* * *}\right)$} & \multicolumn{3}{|c|}{$0.88\left(\mathrm{~F}=11.21^{* \prime}\right)$} \\
\hline $\operatorname{LSD}_{\text {varictics }}(\mathrm{P}=0.05)$ & \multicolumn{3}{|c|}{$4.32\left(\mathrm{~F}=1.67^{\mathrm{ns}}\right)$} & \multicolumn{3}{|c|}{$2.04\left(\mathrm{~F}=3.49^{\mathrm{ns}}\right)$} \\
\hline
\end{tabular}

The $\operatorname{LSD}(\mathrm{P}=0.05)$ for tillage systems and wheat varieties are shown. F-test ratios are from ANOVA. ${ }^{* * *},{ }^{* * *}$ Significant at $\mathrm{P}=0.05, \mathrm{P}=0.01$ and $\mathrm{P}=0.001$, respectively, ns: not significant

Tab. 4. Influence of tillage system (conventional tillage: CT, minimum tillage: MT and no-tillage: NT) and wheat varieties ('Siette, 'Panifor', 'Myrto,' 'Estero') on 1000-grain weight (g) and ear length of wheat, in Athens and in Agrinio

\begin{tabular}{|c|c|c|c|c|c|c|}
\hline \multirow{3}{*}{$\begin{array}{c}\text { Varieties } \\
\text { 1000-grain } \\
\text { weight }(\mathrm{g})\end{array}$} & \multicolumn{6}{|c|}{ Tillage system } \\
\hline & \multicolumn{3}{|c|}{ Athens } & \multicolumn{3}{|c|}{ Agrinio } \\
\hline & $\mathrm{CT}$ & NT & MT & $\mathrm{CT}$ & NT & MT \\
\hline 'Siette' & 43.20 & 39.92 & 40.46 & 43.74 & 41.03 & 41.46 \\
\hline 'Panifor' & 43.42 & 41.04 & 41.44 & 43.53 & 41.76 & 41.54 \\
\hline 'Myrto' & 45.55 & 41.69 & 42.92 & 45.76 & 42.49 & 42.73 \\
\hline 'Estero' & 46.87 & 41.72 & 43.28 & 45.73 & 42.72 & 43.45 \\
\hline $\mathrm{LSD}_{\text {tillage }}(\mathrm{P}=0.05)$ & \multicolumn{3}{|c|}{$0.18\left(\mathrm{~F}=10.96^{*}\right)$} & \multicolumn{3}{|c|}{$0.34(\mathrm{~F}=7.34)$} \\
\hline $\operatorname{LSD}_{\text {varictic }}(\mathrm{P}=0.05)$ & \multicolumn{3}{|c|}{$0.34\left(\mathrm{~F}=12.94 \mathrm{w}^{\prime \prime}\right)$} & \multicolumn{3}{|c|}{$0.44\left(\mathrm{~F}=10.43^{\prime \prime}\right)$} \\
\hline Ear length $(\mathrm{cm})$ & $\mathrm{CT}$ & NT & MT & CT & NT & MT \\
\hline 'Siette' & 9.93 & 9.57 & 9.97 & 9.73 & 9.61 & 9.59 \\
\hline 'Panifor' & 9.70 & 9.82 & 9.65 & 9.78 & 9.76 & 9.87 \\
\hline 'Myrto' & 9.82 & 10.30 & 10.31 & 9.65 & 9.87 & 9.71 \\
\hline 'Estero' & 9.70 & 9.42 & 10.05 & 9.74 & 9.63 & 9.67 \\
\hline $\mathrm{LSD}_{\text {tillage }}(\mathrm{P}=0.05)$ & \multicolumn{3}{|c|}{$0.76\left(\mathrm{~F}=0.81^{\mathrm{ns}}\right)$} & \multicolumn{3}{|c|}{$0.45\left(\mathrm{~F}=1.34^{\mathrm{ns}}\right)$} \\
\hline $\mathrm{LSD}_{\text {varictic }}(\mathrm{P}=0.05)$ & \multicolumn{3}{|c|}{$1.22\left(\mathrm{~F}=1.29^{\mathrm{ns}}\right)$} & \multicolumn{3}{|c|}{$0.56\left(\mathrm{~F}=2.12^{\mathrm{ns}}\right)$} \\
\hline
\end{tabular}

The LSD $(\mathrm{P}=0.05)$ for tillage systems and wheat varieties are shown. F-test ratios are from Anova. ${ }^{*},{ }^{* *},{ }^{* *}$ Significant at $\mathrm{P}=0.05, \mathrm{P}=0.01$ and $\mathrm{P}=0.001$, respectively, ns: not significant

Yield was influenced by both the tillage system and variety (Tab. 5). The highest grain yields were found under the CT system (421-459 $\left.\mathrm{kg} \mathrm{ha}^{-1}\right)$ with 'Siette', 'Myrto' and 'Estero' varieties. In contrast, for the 'Panifor' variety, the highest grain yield was observed under conservation tillage (NT and MT). Munoz-Romero et al. (2010) reported that under rain-fed Mediterranean Vertisol, wheat pro-
Tab. 5. Influence of tillage system (conventional tillage: CT, minimum tillage: MT and no-tillage: NT) and wheat varieties ('Siette, 'Panifor,' 'Myrto,' 'Estero') on yield $\left(\mathrm{kg} \mathrm{ha}^{-1}\right)$ and protein content (\%) of wheat, in Athens and in Agrinio

\begin{tabular}{|c|c|c|c|c|c|c|}
\hline \multirow{3}{*}{$\begin{array}{c}\text { Varieties } \\
\text { Yield }\left(\mathrm{kg} \mathrm{ha}^{-1}\right)\end{array}$} & \multicolumn{6}{|c|}{ Tillage system } \\
\hline & \multicolumn{3}{|c|}{ Athens } & \multicolumn{3}{|c|}{ Agrinio } \\
\hline & CT & NT & MT & CT & NT & MT \\
\hline 'Siette' & 421 & 399 & 360 & 414 & 388 & 365 \\
\hline 'Panifor' & 297 & 363 & 380 & 302 & 374 & 384 \\
\hline 'Myrto' & 432 & 380 & 334 & 427 & 390 & 345 \\
\hline 'Estero' & 459 & 397 & 430 & 448 & 384 & 426 \\
\hline $\mathrm{LSD}_{\text {tillage }}(\mathrm{P}=0.05)$ & \multicolumn{3}{|c|}{$25.32\left(\mathrm{~F}=4.45^{*}\right)$} & \multicolumn{3}{|c|}{$21.02\left(\mathrm{~F}=6.37^{*}\right)$} \\
\hline $\mathrm{LSD}_{\text {varictics }}(\mathrm{P}=0.05)$ & \multicolumn{3}{|c|}{$19.29\left(\mathrm{~F}=4.63^{*}\right)$} & \multicolumn{3}{|c|}{$14.34\left(\mathrm{~F}=7.63^{*}\right)$} \\
\hline Protein content $\%$ & $\mathrm{CT}$ & NT & MT & $\mathrm{CT}$ & NT & MT \\
\hline 'Siette' & 11.43 & 11.85 & 11.15 & 11.12 & 11.24 & 11.18 \\
\hline 'Panifor' & 11.81 & 12.14 & 12.22 & 11.72 & 11.83 & 11.78 \\
\hline 'Myrto' & 12.02 & 12.38 & 12.62 & 11.89 & 12.12 & 12.21 \\
\hline 'Estero' & 12.96 & 12.92 & 13.22 & 12.45 & 12.62 & 12.69 \\
\hline $\mathrm{LSD}_{\text {tillage }}(\mathrm{P}=0.05)$ & \multicolumn{3}{|c|}{$1.02\left(\mathrm{~F}=0.48^{\mathrm{ns}}\right)$} & \multicolumn{3}{|c|}{$0.66\left(\mathrm{~F}=1.23^{\mathrm{ns}}\right)$} \\
\hline $\mathrm{LSD}_{\text {varictics }}(\mathrm{P}=0.05)$ & \multicolumn{3}{|c|}{$0.78\left(\mathrm{~F}=13.49^{* * *}\right)$} & \multicolumn{3}{|c|}{$0.44\left(\mathrm{~F}=21.09^{* * *}\right)$} \\
\hline
\end{tabular}

The LSD $(\mathrm{P}=0.05)$ for tillage systems and wheat varieties are shown. F-test ratios are from Anova. ${ }^{*},{ }^{* *}$ Significant at $\mathrm{P}=0.05$ and $\mathrm{P}=0.001$, respectively, ns: not significant

ductivity is greater under NT due to better root system development. Moreover, De Vita et al. (2007) observed that the superior effect of NT on wheat yield in comparison to CT was due to lower water evaporation from soil combined with enhanced soil water availability. Sip et al. (2009) reported that the reduced tillage system combined with high input level delivered a yield advantage for all the wheat varieties tested.

\section{Wheat quality}

The assessment of wheat flour quality is a great importance for the wheat industry. High quality wheat grains are required for the milling and baking industries. Several physicochemical tests are employed in quality evaluation of wheat. Protein content, Zeleny sedimentation test and Hagberg falling number method are used to access the quality of wheat flours (Colombo et al., 2008; De Vita et al., 2007; Mares and Mrva, 2008). The sedimentation index (Zeleny test) measures the sedimentation volume of a suspension of flour in dilute lactic acid. Colombo et al. (2008) reported that the Zeleny test value was strongly correlated with bread loaf volume.

The Hagberg falling number test is a widely accepted, rapid test for determining the $\alpha$-amylase activity of wheat. As the amount of enzyme activity increases, the falling number decreases. Many countries use the falling number method at grain receival and as a component of trade specifications. Hagberg falling numbers above 250,300 , or in some cases 350 , sec are required for inclusion of delivered grain in high-quality grades depending on the standards set by the wheat industries (Mares and Mrya, 2008). Low values of Hagberg falling number cause loaves to be dis- 
32

Tab. 6. Influence of tillage system (conventional tillage: CT, minimum tillage: MT and no-tillage: NT) and wheat varieties ('Siette,' 'Panifor,' 'Myrto,' 'Estero') on Zeleny value $\left(\mathrm{cm}^{-3}\right)$ and Hagberg falling number (sec) of flour, in Athens and in Agrinio

\begin{tabular}{|c|c|c|c|c|c|c|}
\hline \multirow{3}{*}{$\begin{array}{c}\text { Varieties } \\
\text { Zeleny value } \\
\left(\mathrm{cm}^{-3}\right)\end{array}$} & \multicolumn{6}{|c|}{ Tillage system } \\
\hline & \multicolumn{3}{|c|}{ Athens } & \multicolumn{3}{|c|}{ Agrinio } \\
\hline & CT & NT & MT & $\mathrm{CT}$ & NT & MT \\
\hline 'Siette' & 19.75 & 19.5 & 19.75 & 25.67 & 25.34 & 25.78 \\
\hline 'Panifor' & 20.25 & 20.75 & 20.5 & 24.97 & 24.79 & 24.61 \\
\hline 'Myrto' & 21.5 & 22 & 20.75 & 25.88 & 25.31 & 25.89 \\
\hline 'Estero' & 23.25 & 24.25 & 23 & 25.44 & 25.17 & 25.46 \\
\hline $\mathrm{LSD}_{\text {tillage }}(\mathrm{P}=0.05)$ & \multicolumn{3}{|c|}{$1.54\left(\mathrm{~F}=0.42^{\mathrm{ns}}\right)$} & \multicolumn{3}{|c|}{$1.08\left(\mathrm{~F}=2.42^{\mathrm{ns}}\right)$} \\
\hline $\mathrm{LSD}_{\text {varictics }}(\mathrm{P}=0.05)$ & \multicolumn{3}{|c|}{$1.14\left(\mathrm{~F}=12.42^{* * *}\right)$} & \multicolumn{3}{|c|}{$1.23\left(\mathrm{~F}=2.34^{\mathrm{ns}}\right)$} \\
\hline $\begin{array}{l}\text { Hagberg falling } \\
\text { number (sec) }\end{array}$ & CT & NT & MT & CT & NT & MT \\
\hline 'Siette' & 437 & 453 & 474 & 324 & 315 & 328 \\
\hline 'Panifor' & 447 & 438 & 475 & 356 & 367 & 362 \\
\hline 'Myrto' & 438 & 434 & 447 & 318 & 323 & 312 \\
\hline 'Estero' & 403 & 408 & 423 & 317 & 309 & 298 \\
\hline $\mathrm{LSD}_{\text {tillage }}(\mathrm{P}=0.05)$ & \multicolumn{3}{|c|}{$4.87\left(\mathrm{~F}=32.48^{\cdots *}\right)$} & \multicolumn{3}{|c|}{$23.02\left(\mathrm{~F}=5.48^{\circ}\right)$} \\
\hline $\mathrm{LSD}_{\text {varictics }}(\mathrm{P}=0.05)$ & \multicolumn{3}{|c|}{$4.23\left(\mathrm{~F}=33.23^{* * *}\right)$} & \multicolumn{3}{|c|}{$50.24\left(\mathrm{~F}=2.63^{\mathrm{ns}}\right)$} \\
\hline
\end{tabular}

The LSD $(\mathrm{P}=0.05)$ for tillage systems and wheat varieties are shown. F-test ratios are from Anova. ${ }^{*},{ }^{* * *}$ Significant at $\mathrm{P}=0.01$ and $\mathrm{P}=0.001$, respectively, ns: not significant

coloured, sticky and of poor texture. High protein concentration is required to impart strength to dough, allowing it to trap the $\mathrm{CO}_{2}$ gas produced during fermentation (Smith and Gooding, 1999).

There were no significant differences in protein content between tillage systems in the present study (Tab. 5). In contrast, De Vita et al. (2007) reported that the highest protein content was obtained under CT (15.5-19.6\% for $\mathrm{CT}$ versus $11.4-14.7 \%$ for NT). In Athens, the highest Hagberg falling number (Tab. 6) was found under MT. The 'Estero' variety had the lowest Hagberg falling number (403-423 sec) in comparison to the other varieties ('Siette', 'Panifor,' 'Myrto'). There were no significant differences in Zeleny sedimentation value between tillage systems ( Tab. 6 ). The Zeleny value had positive and significant correlation with protein content $(\mathrm{r}=0.45, \mathrm{P}<0.01)$ in agreement with Colombo et al. (2008). Gursoy et al. (2010) found that tillage had a significant effect on grain yield and test weight, but did not significantly influence protein content and sedimentation. The 'Estero' variety had the highest Zeleny sedimentation value $\left(23-24.25 \mathrm{~cm}^{3}\right)$ in comparison to the other varieties ('Siette', 'Panifor', 'Myrto'). Hagberg falling number had negative and significant correlation with protein content and Zeleny value $(r=-0.54$, $\mathrm{P}<0.001$ and $\mathrm{r}=-0.35, \mathrm{P}<0.05$, respectively). Grain quality is a complex characteristic that depends on a number of factors such as genotype and location (Colombo et al., 2008; Kilic and Yagbasanlar, 2010; Zecevic et al., 2009). Hagberg falling number is almost exclusively influenced by environment and genotypic main effects (Grausgruber et al., 2000).
In Agrinio, concerning the wheat quality (Hagberg falling number and Zeleny value), there were no significant differences between treatments. The Hagberg falling number and Zeleny value in Athens were always higher than those in Agrinio. The main reason for lower wheat quality in Agrinio may be attributed to precipitation there during the harvest period. Pre-harvest sprouting and high $\alpha$-amylase activity are the most serious problems for wheat production in some areas. It has become more frequent for wheat to be exposed to continuous rain for several days at harvest time (Yanagisawa et al., 2005).

\section{Conclusions}

Our results indicate that high quality flour (high protein content and Zeleny value and low Hagberg falling number) was produced by the 'Estero' variety. Comparing the four varieties, it has been found that the 'Panifor' variety cultivated under the conservation tillage had higher yield. In contrast, the highest grain yield was found under the CT system with 'Siette', 'Myrto' and 'Estero' varieties. Moreover, there were no significant differences between the tillage systems concerning the protein content and Zeleny value. Finally, reducing tillage intensity improved the Hagberg falling number of wheat flour.

\section{References}

Alvarez R (2005). A review of nitrogen fertilizer and conservation tillage effects on soil organic carbon storage. Soil Use Manag 21:38-52.

Alvaro-Fuentes J, Lopez MV, Arrue JL, Moret D, Paustian K (2009). Tillage and cropping effects on soil organic carbon in Mediterranean semiarid agro ecosystems: Testing the Century model. Agric Ecosystem Environ 134:211-217.

Annicchiarico P, Chiappariino E, Perenzin M (2010). Response of common wheat varieties to organic and conventional production systems across Italian locations, and implications for selection. Field Crops Res 116:230-238.

Bhattacharyya R, Kundu S, Pandey SC, Singh KP, Gupta HS (2008). Tillage and irrigation effects on crop yields and soil properties under the rice-wheat system in the Indian Himalayas. Agric Water Manag 95:993-1002.

Bilalis D, Efthimiadis P, Sidiras N (2001). Influence of three tillage systems on weed flora in a 3-year rotation. J Agron Crop Sci 186:135-141

Bilalis D, Sidiras N, Vavoulidou E, Konstantas A (2009). Earthworm populations as affected by crop practices on clay loam soil in a Mediterranean climate. Acta Agric Scand Sect B-Soil Plant Sci 59:440-446.

Bilalis DJ, Karkanis A, Papastylianou P, Patsiali S, Athanasopoulou M, Barla G, Kakabouki I (2010). Response of organic linseed (Linum usitatissimum L.) to the combination of tillage systems (minimum, conventional and no-tillage) and fertilization practices: Seed and oil yield production. Aust J Crop Sci 4:700-705. 
Bremner JM (1960). Determination of nitrogen in soil by Kjedahl method. J Agric Sci 55:11-33.

Cantero-Martinez C, Angas P, Lampurlanes J (2007). Longterm yield and water-use efficiency under various tillage systems in Mediterranean rain-fed conditions. Ann Appl Bot 150:293-305.

Cavalieri KMV, Pires da Silva A, Tormena CA, Leao TP, Dexter AR, Hakansson I (2009). Long-term effects of no-tillage on dynamic soil physical properties in a Rhodic Ferrasol in Parana, Brazil. Soil Tillage Res103:158-164.

Colombo A, Perez GT, Ribotta PD, Leon AE (2008). A comparative study of physicochemical tests for quality prediction of Argentine wheat flours used as corrector flours and for cookie production. J Cereal Sci 48:775-780.

Daraghmeh OA, Jensen JR, Petersen CT (2009). Soil structure stability under conventional and reduced tillage in a sandy loam. Geoderma 150:64-71.

De Vita P, Di Paolo E, Fecondo G, Di Fonzo N, Pisante M (2007). No-tillage and conventional tillage effects on durum wheat yield, grain quality and soil moisture content in southern Italy. Soil Tillage Res 92:69-78.

EC 834/2007. Council Regulation (EC) No 834/2007 of 28 June 2007 on organic production and labelling of organic products and repealing Regulation (EEC) No 2092/91. The Council of the European Union. Off J Eur Union L189/1$189 / 23$.

Grausgruber H, Obeforster M, Wereker M, Ruckenbauer P, Vollmann J (2000). Stability of quality traits in Austriangrown winter wheat. Field Crops Res 66:257-267.

Gursoy S, Sessiz A, Malhi SS (2010). Short-term effects of tillage and residue management following cotton on grain yield and quality of wheat. Field Crops Res 119:260-268.

Hagberg S (1960). A rapid method for determining alphaamylase activity. Cereal Chem 37:218-222.

ISO 3093 (2004). Wheat, rye and respective flours, durum wheat and durum wheat semolina-Determination of the Falling Number according to Hagberg-Perten. International Standard.

ISO 5529 (2007). Wheat-Determination of the sedimentation index-Zeleny test. International Standard.

Kilic H, Yagbasanlar T (2010). The effect of drought stress on grain yield, yield components and some quality traits of durum wheat (Triticum turgidum ssp. durum) cultivars. Not Bot Horti Agrobo 38(1):164-170

Lammerts van Bueren ET, Jones SS, Tamm L, Murphy KM, Myers JR, Leifert C, Messmer MM (2010). The need to breed crop varieties suitable for organic farming, using wheat, tomato and broccoli as examples: A review. NJAS-Wagening J Life Sci (in press) doi:10.1016/j.njas.2010.04.001.
László P, Dombos M, Gyuricza C (2007). The effect of conservation tillage systems on sustainability of soil biological state of sandy loam soil in corn monoculture. Cereal Res Commun 35:721-724.

Li QQ, Zhou XB, Chen YH, Yu SL (2010). Grain yield and quality of winter wheat in different planting patterns under deficit irrigation regimes. Plant Soil Environ 56:482-487.

Mares D, Mrva K (2008). Review: Late-maturity a-amylase: Low falling number in wheat in the absence of preharvest sprouting. J Cereal Sci 47:6-17.

Mrabet R (2000). Differential response of wheat to tillage management systems in a semiarid area of Morocco. Field Crops Res 66:165-174.

Munoz-Romero V, Benitez-Vega J, Lopez-Bellido L, LopezBellido RJ (2010). Monitoring wheat root development in a rainfed vertisol: Tillage effect. Eur J Agron 33:182-187.

Peigne J, Ball BC, Roger-Estrade J, David C (2007). Is conservation tillage suitable for organic farming? A review. Soil Use Manag 23:129-144.

Sasal MC, Andriulo AE, Taboada MA (2006). Soil porosity characteristics and water movement under zero tillage in silty soils in Argentinean Pampas. Soil Tillage Res 87:9-18.

Sidiras N, Bilalis D, Vavoulidou E (2001). Effects of tillage and fertilization on some selected physical properties of soil (0-30 cm depth) and on the root growth dynamic of winter barley (Hordeum vulgare cv. 'Niki'). J Agron Crop Sci 187:167-176.

Sip V, Ruzek P, Chrpova J, Vavera R, Kusa H (2009). The effect of tillage practice, input level and environment on the grain yield of winter wheat in the Czech Republic. Field Crops Res 113:131-137.

Smith GP, Gooding MJ (1999). Models of wheat grain quality considering climate, cultivar and nitrogen effects. Agric For Meteorol 94:159-170.

Statsoft Inc. (1996). Statistica for Windows, Statsoft, Inc., Tulsa, OK, USA.

Tangyuan N, Bin H, Nianyuan J, Shenzhong T, Zengjia L (2009). Effects of conservation tillage on soil porosity in maize-wheat cropping system. Plant Soil Environ 55:327333.

Wuest SB (2001). Soil biopore estimation: effects of tillage, nitrogen and photographic resolution. Soil Tillage Res 62:111-116.

Yanagisawa A, Nishimura T, Amano Y, Torada A, Shibata S (2005). Development of winter wheat with excellent resistance to pre-harvest sprouting and rain damage. Euphytica 143:313-318.

Zecevic V, Knezevic D, Boskovic J, Madic M (2009). Effect of genotype and environment on wheat quality. Genetica 41:247-253. 